\title{
Ethnopolitics in Central and Eastern Europe in a State of Flux
}

\section{Vassilis Petsinis}

To cite this article: Vassilis Petsinis (2019): Ethnopolitics in Central and Eastern Europe in a State of Flux, Ethnopolitics

To link to this article: https://doi.org/10.1080/17449057.2019.1613067

望 Published online: 28 May 2019.

Submit your article to this journal ¿

View Crossmark data ¿ 


\title{
INTRODUCTION
}

\section{Ethnopolitics in Central and Eastern Europe in a State of Flux*}

\author{
VASSILIS PETSINIS \\ University of Tartu, Estonia
}

The end of the Cold War witnessed the dynamic return of identity politics across Central and Eastern Europe. In light of the persisting controversies over their collective statuses, the question of ethnic minorities became securitized throughout this macro-region. Throughout the 1990s, a series of governments rushed to securitize the question of ethnic minorities in their states' interior (e.g. the Slovak and Romanian cases) and/or closely monitor the situation of the ethnic kin in neighbouring states (e.g. Hungary vis-àvis the ethnic Hungarian minorities in Romania, Slovakia and Serbia), (Auer, 2000; Szabo, 1994). This saw the gradual emergence of a quadratic nexus that consisted of: ethnic minorities; their external homelands (or kin states); the (frequently) nationalizing states where the minorities are based; and, later, the EU's soft power diplomacy as a fourth (both regulatory and normative) pillar (Brubaker, 1995; Bruszt \& Stark, 2003; Budryte, 2005; Haughton, 2007; Pettai, 2006; Smith, 2002, 2003).

Since the 2000s, the internal balance within this nexus has become subject to several readjustments. The initial stage might be dubbed the phase of optimism. Systemic transformation facilitated the formulation of an extensive legislation on minority rights in certain states (e.g. Serbia and Croatia) (Petsinis, 2013; Vasilijević, 2002). Political parties that represent the interests of minority groups shifted from the politics of confrontation towards the politics of consensus and participated in grand coalition governments with larger, mainstream, partners (e.g. the case of the ethnic Hungarian parties in Romania and Slovakia) (Craiutu, 1995). Meanwhile, EU-membership functioned as the pole of attraction that relaxed the emphasis on national survival and encouraged the improvement of minority rights in certain states (e.g. Estonia and Latvia) (Mole, 2012; Van Elsuwege, 2004). Further to the southeast, the international community became actively engaged in an endeavour to

\footnotetext{
*A special section based on selected contributions for the 'Ethnopolitics in Central and Eastern Europe in a State of Flux' international conference (UPTAKE research consortium, Johan Skytte Institute of Political Studies, University of Tartu, Estonia, 9-10 February 2018).

Correspondence Address: Johan Skytte Institute of Political Studies, University of Tartu, Tartu, Estonia. Email: vasileios.petsinis@ut.ee
} 


\section{V. Petsinis}

pacify contentious nexuses that consist of states, ethnic minorities and their external homelands (e.g. the Ohrid Peace Agreement of 2001 in the Republic of North Macedonia).

The current stage might be regarded as the phase of crisis(-es). Geopolitical realignments across the Continent and the emergence of Eurosceptic trends within the EU have exerted a powerful impact on the state of ethnic relations in Central and Eastern Europe. In the northeast, Russia has been decisively reassuming its role as an external homeland and has become active in its endeavour to win hearts and minds, via informal channels, among the ethnic Russian minorities of Estonia and Latvia (Berzina, 2016; Cianetti \& Nakai, 2017; Kaprans \& Mierina, 2019). Populist and radical right-wing parties have augmented their public appeal, embedding staunch opposition to minority rights and immigration into the broader frame of their Eurosceptic agendas (e.g. the cases of Estonia, Latvia, Slovakia and Hungary) (Kasekamp, Madison, \& Wierenga, 2018; Kluknavská \& Smolik, 2016; Kovarek, Róna, Hunyadi, \& Krekó, 2017; Braghiroli \& Petsinis, 2019). Furthermore, EU-membership has lost much of its attraction among candidate states in the region (e.g. the case of Serbia) whilst the alleged prospective influx of war refugees from the Middle East is likely to reshape identity perceptions on the everyday level of social interaction.

This special section comprises three contributions that featured at the 'Ethnopolitics in Central and Eastern Europe in a State of Flux' international conference which was held at the University of Tartu (Johan Skytte Institute of Political Studies) between 9-10 February and 2018. ${ }^{1}$ This thematic conference was organized within the frame of the UPTAKE research consortium (Horizon 2020) which brought together the universities of Tartu (the Johan Skytte Institute of Political Studies), Uppsala (the Institute for Russian and Eurasian Studies/IRES) and Kent (the Global Europe Centre at the Department of Politics and International Relations). ${ }^{2}$ It concentrated on the shifting patterns in the state of ethnic relations and conflict resolution in contemporary Central and Eastern Europe. The geographic scope comprised regions as diverse as Southeast Europe, the 'Visegrad Four' group of states, the Baltic States, Ukraine and other parts of the post-Soviet space (e.g. the Caucasus).

The key objectives were to: (a) take stock of the state of ethnic relations across Central and Eastern Europe, with due attention to cross-national differences and regional specifics; (b) facilitate cross- and interdisciplinary exchange and allow participants to embed their research more solidly into the wider regional and European contexts; (c) establish a network of cooperation among academic and non-academic experts. The core themes of the conference revolved around: (a) the institutional and legal developments in the management of ethnic relations and minority rights (i.e. the European, regional and national dimensions); (b) the spectrum of ethnic relations and conflict resolution in Central and Eastern Europe (i.e. the political and security implications); (c) the longer trajectory and grassroots dimensions of ethnopolitics in Central and Eastern Europe (i.e. the historical and sociocultural specificities).

The first contribution in this special section, authored by Pavlos N. Koktsidis (University of Cyprus), is entitled: 'The Decision to Use Violence: Opportunity Structures and the Albanian Insurgency in the Former Yugoslav Republic of Macedonia'. The key-argument of this case study is that the decision of group actors to use organized violence depends on the perception of structural conditions conducive to the emergence of violence: ethnospatial factors; operational factors; international factors; and state response. This article contributes empirical material towards the formulation of a conceptual framework for the study of violent conflict that allows scholars to examine more consistently the variables related to the feasibility of violent conflict. The author argues that a comparative 
examination of variables across conflicts is equally important for identifying and analysing non-agreeable cases of violent and non-violent conflict.

The second contribution, authored by Raivo Vetik (University of Tallinn), is entitled: 'National Identity as Interethnic (de)mobilization: A Relational Approach'. The author argues that national identity represents not merely an unmediated connection between an individual and a nation but a connection which relies on the different types of relationship between majority and minority subject positions in the interethnic field. The empirical section of the article carries out a demonstrative type of study of national identity among ethnic Estonians and Estonian Russians. These two groups were interviewed in a survey within the research project 'Integration Monitoring of Estonian Society 2017'. The conclusion calls for designing better targeted national integration policies, based on the theoretical advancement offered by the relational approach.

The third contribution, authored by Igor Mitchnik (Mercator Fellow on International Affairs 2018/2019), is entitled: 'Making Donbas, Breaking Donbas-the Impact of Conflict Experience on Identity Shifts in the East of Ukraine'. This is a qualitative case study which critically investigates the interrelation of changes in socio-political attitudes and identity of civilian population under circumstances of war via comparing youth attitudes in two cities in the Donbas region of Ukraine. This article hints that a stronger experience of conflictrelated clashes has an impact on how negatively the researched youth groups perceive Russia politically, and the local separatist movement, and on how positively they relate to nationalizing trends by the Ukrainian government.

\section{Notes}

1. http://www.uptake.ut.ee/cfp-ethnopolitics-in-central-and-eastern-europe-in-a-state-of-flux/?fbclid= IwAR1j23sSZUxiXMUyiB1smq6iGOMqcWtr2SE4u4Ze_p-VOOSVCDRHSWEtMXg (accessed on 18 March 2019).

2. http://www.uptake.ut.ee/ (accessed on 18 March 2019).

\section{References}

Auer, S. (2000). Nationalism in Central Europe-a chance or a threat for the emerging liberal democratic order? East European Politics and Societies, 14(2), 213-245.

Berzina, I. (2016). The possibility of societal destabilization in Latvia: Potential national security threats. Riga: National Defense Academy of Latvia.

Braghiroli, S., \& Petsinis, V. (2019). Between party-systems and identity-politics: The populist and radical right in Estonia and Latvia. European Politics and Society (online version). doi:10.1080/23745118.2019.1569340

Brubaker, R. (1995). National minorities, nationalizing states and external homelands in the New Europe. Daedalus, 124(2), 107-132.

Bruszt, L., \& Stark, D. (2003). Who counts? Supranational norms and societal needs. East European Politics and Societies, 17(1), 74-82.

Budryte, D. (2005). Taming nationalism? Political community building in the post-soviet Baltic States. Aldershot: Ashgate.

Cianetti, L., \& Nakai, R. (2017). Critical trust in European institutions: The case of the Russian-speaking minorities in Estonia and Latvia. Problems of Post-Communism, 64(5), 276-290.

Craiutu, A. (1995). A dilemma of dual identity: The democratic alliance of Hungarians in Romania. East European Constitutional Review, 4(2), 43-49.

Haughton, T. (2007). When does the EU make a difference? Conditionality and the accession process in Central and Eastern Europe. Political Studies Review, 5, 233-246.

Kaprans, M., \& Mierina, I. (2019). Minority reconsidered: Towards a typology of Latvia's Russophone identity. Europe-Asia Studies, 71(1), 24-47. 


\section{V. Petsinis}

Kasekamp, A., Madison, M., \& Wierenga, L. (2018, April). Discursive opportunities for the Estonian populist radical right in a digital society. Problems of Post-Communism (online version). doi:10.1080/10758216. 2018.1445973

Kluknavská, A., \& Smolik, J. (2016). We hate them all? Issue adaptation of extreme right parties in Slovakia 19932016. Communist and Post-Communist Studies, 49(4), 335-344.

Kovarek, D., Róna, D., Hunyadi, B., \& Krekó, P. (2017). Scapegoat-based policy-making in Hungary: Qualitative evidence for how Jobbik and its mayors govern municipalities. Intersections, 3(3), 63-87.

Mole, R. (2012). The Baltic states from the Soviet Union to the European Union: Identity, discourse and power in the post-communist transition of Estonia, Latvia and Lithuania. London: Routledge.

Petsinis, V. (2013). Croatia's framework for minority rights: New legal prospects within the context of European integration. Ethnopolitics, 12(4), 352-367.

Pettai, V. (2006). Explaining ethnic politics in the Baltic States: Reviewing the triadic nexus model. Journal of Baltic Studies, 37(1), 124-136.

Smith, D. (2002). Framing the national question in Central and Eastern Europe: A quadratic nexus? The Global Review of Ethnopolitics, 2(1), 3-16.

Smith, D. (2003). Minority rights, multiculturalism, and EU-enlargement: The case of Estonia. Journal on Ethnopolitics and Minority Issues in Europe, 1, 1-39.

Szabo, M. (1994). Nation-state, nationalism and the prospects for democratization in East Central Europe. Journal of Communist and Post-Communist Studies, 27(4), 377-399.

Van Elsuwege, P. (2004). Russian-speaking minorities in Estonia and Latvia: Problems of integration at the threshold of the European Union. Flensburg: ECMI Press.

Vasilijević, S. (2002). The legal aspects of the protection of minorities in the process of stabilization and association. In K. Ott (Ed.), Croatian accession to the EU: Institutional challenges (Vol. 2, pp. 249-272). Zagreb: Institute of Public Finance. 